University of Nebraska - Lincoln

DigitalCommons@University of Nebraska - Lincoln

Nebraska Cooperative Fish \& Wildlife Research Nebraska Cooperative Fish \& Wildlife Research Unit -- Staff Publications

2021

\title{
Roost Use and Movements of Northern Long-Eared Bats in a Southeast Nebraska Agricultural Landscape
}

Christopher Fill

Craig R. Allen

John F. Benson

Dirac Twidwell

Follow this and additional works at: https://digitalcommons.unl.edu/ncfwrustaff

Part of the Aquaculture and Fisheries Commons, Environmental Indicators and Impact Assessment Commons, Environmental Monitoring Commons, Natural Resource Economics Commons, Natural Resources and Conservation Commons, and the Water Resource Management Commons

This Article is brought to you for free and open access by the Nebraska Cooperative Fish \& Wildlife Research Unit at DigitalCommons@University of Nebraska - Lincoln. It has been accepted for inclusion in Nebraska Cooperative Fish \& Wildlife Research Unit -- Staff Publications by an authorized administrator of DigitalCommons@University of Nebraska - Lincoln. 


\title{
Roost Use and Movements of Northern Long-Eared Bats in a Southeast Nebraska Agricultural Landscape
}

\author{
CHRISTOPHER T. FILL ${ }^{1}$ \\ Nebraska Cooperative Fish and Wildlife Research Unit, and School of Natural Resources, University of Nebraska- \\ Lincoln, 3310 Holdrege Street, Lincoln 68583 \\ CRAIG R. ALLEN AND JOHN F. BENSON \\ School of Natural Resources, University of Nebraska-Lincoln, 3310 Holdrege Street, Lincoln 68583 \\ AND \\ DIRAC TWIDWELL \\ Department of Agronomy and Horticulture, University of Nebraska-Lincoln, $1825 \mathrm{~N} 38^{\text {th }}$ Street, Lincoln 68503
}

\begin{abstract}
Bats are important bio-indicators of ecosystem health and provide a number of ecosystem services. White-nose Syndrome and habitat loss have led to the decline of many bat species in eastern North America, including the federally threatened northern long-eared bat, Myotis septentrionalis. White-nose Syndrome was only recently found in Nebraska, which lies on the western extent of this species geographic range. To better understand how this forestdependent species persists in an agriculturally dominated landscape amid a growing number of pressures, we investigated the roosting habits of this bat at the Homestead National Monument of America, located in southeast Nebraska. We mist-netted bats on eight nights in 2019 (16 August-26 August) and caught 55 bats across five species, including five juvenile northern long-eared bats. We located five unique roosts between two juvenile radio-tracked bats; most of the female roosts were in anthropogenic structures and tree cavities within 0.23 $\mathrm{km}$ of capture, while most of the male roosts were in snags and tree cavities as far as $2.73 \mathrm{~km}$ from the capture site. Fence cavities were also used by other undocumented northern longeared bats. We recorded three radio-tagged bats that commuted between roosting sites and capture sites within hours after sunset. Our results provide evidence that at the distributional edge for this species, wooded areas, riparian zones, and human-built structures in an intensively managed agricultural landscape are used by this imperiled species.
\end{abstract}

\section{INTRODUCTION}

Destruction of habitat is a primary cause for biodiversity loss (Tilman et al., 2001; Prescott et al., 2015). To feed increasing human populations, conversion of land to agriculture is likely to increase. Consequently, it is important to understand how wildlife exploits available resources to allow continued persistence in these human-modified landscapes.

The northern long-eared bat (Myotis septentrionalis) is a small, insectivorous species found throughout much of the eastern United States and Canada (Caceres and Barclay, 2000). These bats glean prey from surfaces and capture it airborne, allowing them to hunt within the complex structure of interior forest habitats to which they are mostly constrained (Patriquin and Barclay, 2003; Ratcliffe and Dawson, 2003; Henderson and Broders, 2008). Northern long-eared bats roost primarily in trees of a variety of types and stages, where females form maternity colonies and males tend to remain solitary (Foster and Kurta, 1999; Broders and Forbes, 2004; Carter and Feldhamer, 2005). Northern long-eared bats are particularly susceptible to White-nose Syndrome (WNS) (Blehert et al., 2015; Frick et al.,

${ }^{1}$ Corresponding author: e-mail: christopher.fill@huskers.unl.edu 
2015) and no longer common throughout much of their range. Consequently, this species was listed as Threatened under the Endangered Species Act by the US Fish and Wildlife Service (FWS) in 2015 (US Fish and Wildlife Service, 2015).

Nebraska lies on the western periphery of the species' range and the fungus that causes WNS was recently detected in Nebraska (White-nosesyndrome.org, 2020). Our objective was to describe late-summer roosting habits in the state's intensively farmed landscape at the Homestead National Monument of America preserve and surrounding areas. Eastern Nebraska is unique in that this is the western limit of the species range, WNS was only documented recently in the region, and most available habitat is due to afforestation following European colonization (Geluso, 2006; Anderson et al., 2017). Because relatively little is known about the ecology of this species in the Great Plains, examination of how these forest-dependent bats use an extremely fragmented agricultural environment will contribute to an understanding of the habitat needs for this species in peril.

\section{Study Area And Methods}

Created in 1936, Homestead National Monument, a Unit of the National Park Service, is located in Gage County in southeast Nebraska's glacial Drift Hill Region, $40^{\circ} 17^{\prime} 16.8857^{\prime \prime} \mathrm{N}$, $96^{\circ} 50^{\prime} 1.9601$ "W. The park covers roughly $79 \mathrm{ha}$, about two-thirds of which is restored native tallgrass prairie, and one-third mature lowland forest along Cub Creek in the western portion of the park. The woodland consists mainly of cottonwood (Populus deltoides), hackberry (Celtis occidentalis), and oak (Quercus spp.). The restored prairie is primarily big bluestem (Andropogon gerardii), little bluestem (Schizachyrium scoparium), and Indiangrass (Sorgastrum nutans) (Robbins, 2005). Private agricultural lands surround the park, and are heavily managed for the production of corn and soybean.

Under FWS federal recovery permit TE02373A-14, we mist-netted for bats on eight nights from 16-24 August 2019 at four sites in forested areas. Each site consisted of 2-4 nets, placed along forest edges, park buildings, waterways, trails, or other spaces used as travel corridors by bats, and sampled one to three nights (Fig. 1). We assembled 2.6-m high black nylon 38$\mathrm{mm}$ mesh bat nets (Avinet Research Supplies, Portland, ME, U.S.A.) that were 6-18 m long, in various stacked setups, depending on the flyway.

We netted each night for at least $5 \mathrm{~h}$ beginning at sunset. We checked nets at approximately $10 \mathrm{~min}$ intervals and recorded weight, right forearm length, age (degree of epiphyseal fusion), sex, reproductive condition (nipple hair for females, testes position for males), and wing damage index (Anthony, 1988; Haarsma, 2008; Reichard and Kunz, 2009) for each bat captured. Following the $<5 \%$ body weight rule for transmitters (Aldridge and Brigham, 1988), a permitted biologist radio tagged each northern long-eared bat with a Holohil radio transmitter (Holohil Systems Ltd., Carp, Ontario, Canada) with Perma-type adhesive (The Perma-Type Company Inc., Plainville, CT, U.S.A.) to track movements and locate daytime roosts. We searched for tagged bats primarily during the daytime using Lotek wireless Biotracker units (Lotek Wireless, Newmarket, Ontario, Canada) and a five-element Yagi antenna, mounted on a truck, driving roads within $4.8 \mathrm{~km}$ of the park boundary. After capturing three northern long-eared bats, we followed this same search procedure for two nights between sunset and 0300, using bi-angulation to approximate flying bat positions. For bats we did not detect, we continued searching at sunset and used a stationary antenna while netting to detect tagged bats. We terminated daily searches for bats undocumented after 1 wk and conducted an emergence count on the first night at each roost, lasting from $30 \mathrm{~min}$ before sunset until dark. 

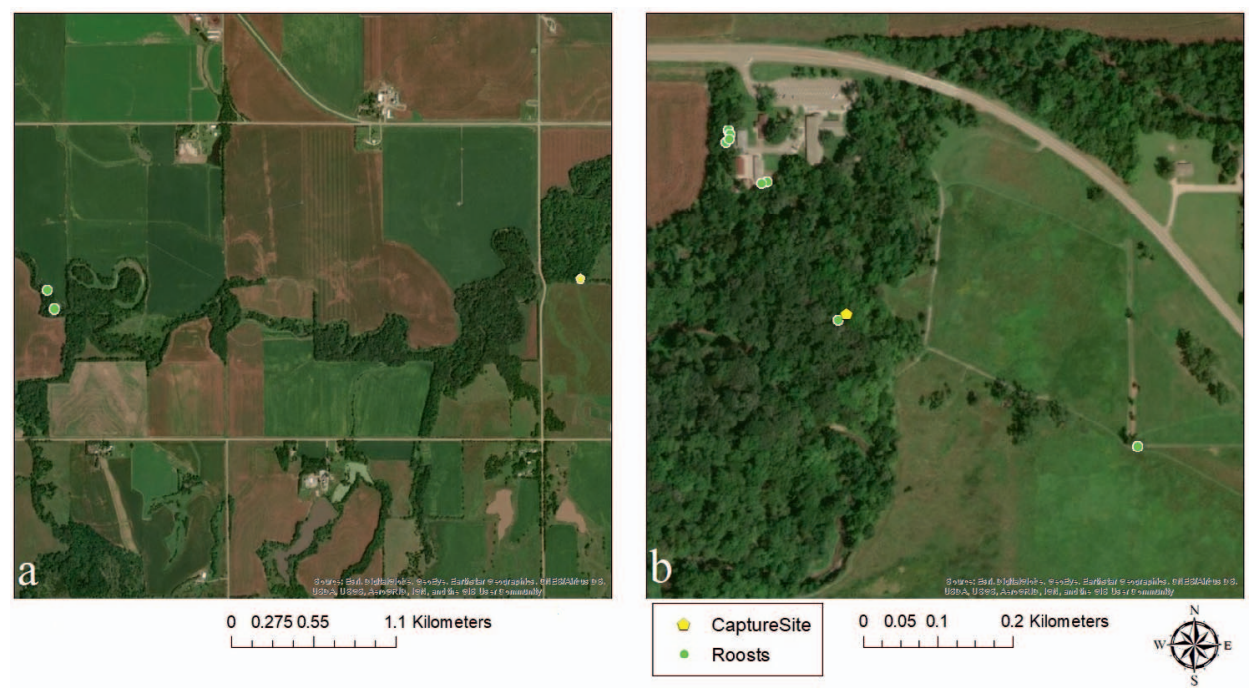

Fig. 1.-Capture and roost locations of northern long-eared bats at Homestead National Monument, Nebraska in August 2019: (1A) male capture and roost locations and (1B) female capture and roost locations. Roosts for the male were located on 18 and 19 August, and from 22 August to 2 September for the female.

\section{RESUlts}

We caught 55 bats across five species, including five northern long-eared bats. We radio tagged four female and one male non-reproductive, volant juveniles with nearly fused joints and no wing tissue damage. Of these, we tracked the male and one female to diurnal roosts. We failed to detect movement by two females within our search area, and were unable to locate any roosts for another female.

\section{ROOSTS}

We found two roosts used by the male. It first used a large slippery elm (Ulmus rubra) about $2.7 \mathrm{~km}$ west of the park, and the following day roosted under a raised slab of bark on a downed limb $0.1 \mathrm{~km}$ east of the elm roost (Table 1, Fig. 1A). This limb was charred by fire in a burned clearing between a corn field and the creek (Fig. 2A). This bat was in the same area the following day, but due to landowner access and personnel constraints, we did not identify additional specific roosts.

We located the one female in cavities beneath the trimmed top of a shadow box fence about $0.2 \mathrm{~km}$ from her capture site (Fig. 1B, Fig. 2B) on 6 of $8 \mathrm{~d}$ following capture. Once she shared a cavity with an unbanded, untagged northern long-eared bat (Fig. 2C), and twice we found only an unbanded, untagged northern long-eared bat in the fence as late as 10 September. For $1 \mathrm{~d}$ this female used a small cavity near the base of a young common hackberry $1 \mathrm{~m}$ from her capture site (Fig. 2D). She shed her transmitter $2 \mathrm{~d}$ later in the cavity of a large cottonwood $0.3 \mathrm{~km}$ east in the prairie portion of the park.

At each roost, we recorded habitat features including tree roost species, diameter at breast height $(\mathrm{DBH})$, tree height, roost height, and percent canopy cover (Table 1). The four roost 
TABLE 1.-Characteristics of roosts used by two volant young northern long-eared bats in Homestead National Monument, Nebraska, U.S.A., from 16 to 24 August 2019, including two roosts for a male and eight for a female. For fence roosts, bats occupied a new cavity each day

\begin{tabular}{lclccccc}
\hline \hline \multicolumn{1}{c}{ Roost species } & $\begin{array}{c}\text { Structure } \\
\text { ht. }(\mathrm{m})\end{array}$ & \multicolumn{1}{c}{ Roost type } & $\begin{array}{c}\text { Roost } \\
\text { ht. }(\mathrm{m})\end{array}$ & $\begin{array}{c}\text { DBH } \\
(\mathrm{cm})\end{array}$ & $\begin{array}{c}\text { Canopy } \\
\text { cover }(\%)\end{array}$ & $\begin{array}{c}\text { Days } \\
\text { per roost }\end{array}$ & $\begin{array}{c}\text { Tracked } \\
\text { bat }\end{array}$ \\
\hline Ulmus rubra & 45 & Unknown & 25 & 74.8 & 25 & 1 & Male \\
Burned snag & 1.75 & Bark & 1.75 & 18.3 & 0 & 1 & Male \\
Fence & 1.82 & Cavity & 1.74 & - & 20 & 4 & Female \\
Celtis occidentalis & 6 & Cavity & 1 & 7.0 & 80 & 1 & Female \\
Fence & 1.67 & Cavity & 1.61 & - & 5 & 2 & Female \\
Populus deltoides & 30 & Cavity/Unknown & 12 & 65.3 & 25 & Unknown* & Female \\
\hline
\end{tabular}

$\mathrm{DBH}=$ diameter at breast height $;-=$ value not available; $*=$ transmitter shed overnight

trees varied from $7-74.8 \mathrm{~cm} \mathrm{DBH}(\bar{X}=41.4 \mathrm{~cm})$ and each was a different species (Table 1). Roost heights were 1-25 m, and included live trees, downed material, and a synthetic fence. Both bats appeared to switch roosts almost every night, with the male and female using two and three structures, respectively. The female also occupied a different cavity on six occasions we found her in the fence.

\section{EMERGENCE COUNTS AND MOVEMENTS}

Emergence counts ranged from one to three bats. Larger trees typically had more counts. Except for one instance in the fence, we counted one emergence each survey at the fence and burnt snag. Due to the length of the fence, we were unable to view the entire structure each survey attempt.

On the day following capture, the male roosted $2.7 \mathrm{~km}$ west of the capture site. We detected the faint signal of a female further west, but did not locate her roost. After emergence that night, we failed to detect either of these bats until midnight, when both had returned to the park. By morning the following day, we found the male in a second roost 0.1 $\mathrm{km}$ east of the first roost, and bi-angulated him flying near the second roost at $0230 \mathrm{~h}$.

After tagging, we tracked the last captured female throughout the remainder of the night until she roosted for the day in a fence $0.2 \mathrm{~km}$ from her capture site, where she also roosted the next night. For each of the next $3 \mathrm{~d}$, she roosted no further than $0.2 \mathrm{~km}$ from the capture site and dropped the transmitter overnight in a tree $0.3 \mathrm{~km}$ away.

\section{Discussion}

These data provide evidence that wooded areas, riparian zones, and human-built structures are used by this imperiled species in a Great Plains agricultural landscape. Eastern Nebraska is currently at the western edge of the spread of WNS, a disease known to cause steep recruitment declines of northern long-eared bats in areas following its arrival (Francl $e t$ al., 2012; Reynolds et al., 2016). Despite this, the presence of juveniles during our short study indicates successful reproduction in this area of Nebraska.

Although we captured no adult northern long-eared bats, it is possible adults already migrated from the area to hibernacula, where they gather for swarming in late August and September (Caceres and Barclay, 2000). In neighboring Otoe County, Stein and White (2016) documented a maternity colony from 21 June-8 October 2014, from which members began disbanding mid-August. However, White et al. (2017) documented northern long- 

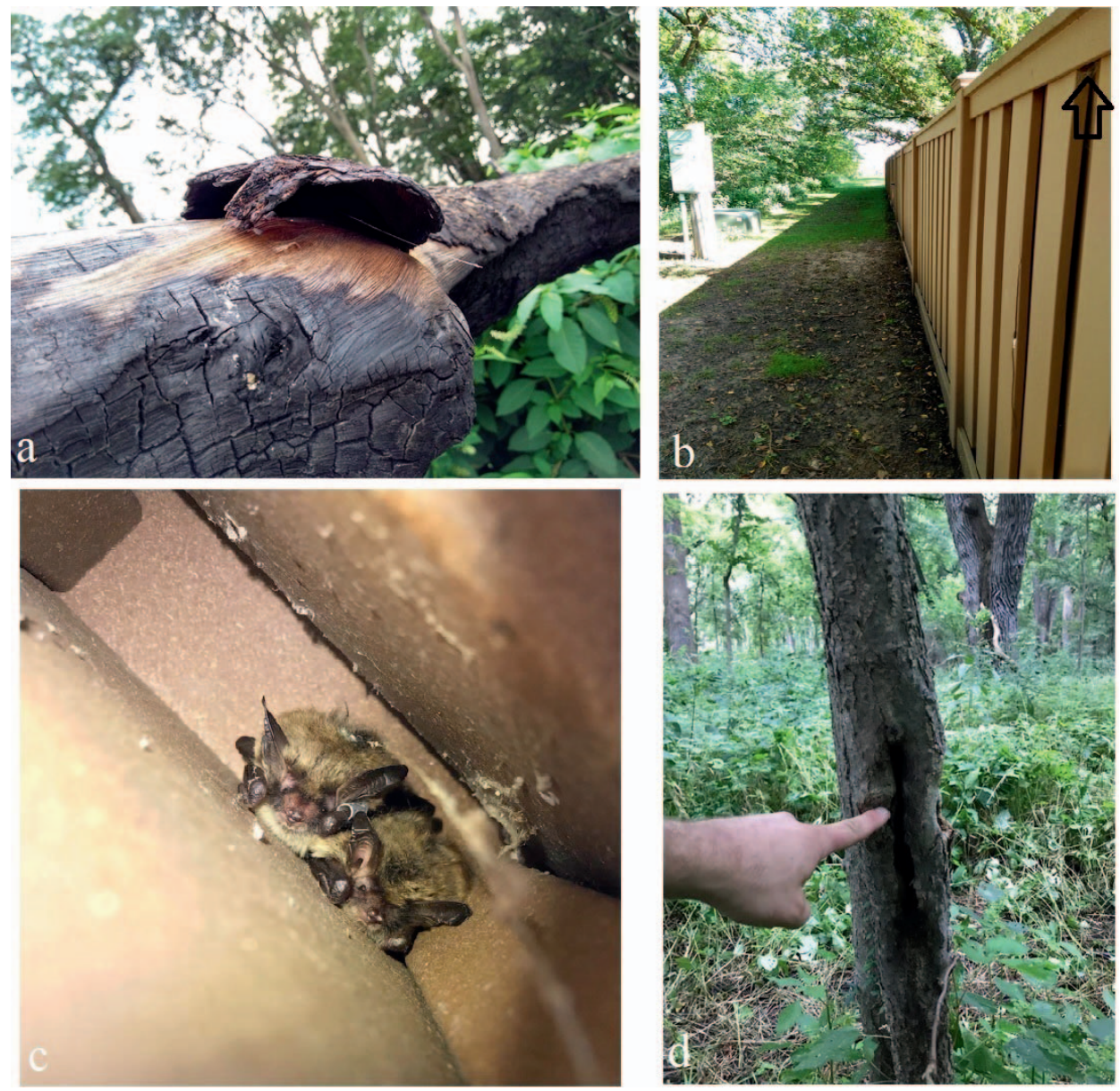

FIg. 2.-Roost sites of northern long-eared bats at Homestead National Monument, Nebraska in August 2019: (2A) burned snag, (2B) shadowbox fence, (2C) two northern long-eared bats in box fence, and (2D) hackberry cavity.

eared bats in nearby Sarpy County through early November, suggesting later migration. While known caves and mines in southeastern Nebraska are in Cass and Sarpy counties, where this species has been found year-round (Czaplewski et al., 1979; White et al., 2016), northern long-eared bats also use crevices in cliff and rock faces during winter, which are slightly more common and widespread in eastern Nebraska (Lemen et al., 2016; White et al., 2020).

Though both juveniles, the male used two roosts, each approximately $2.7 \mathrm{~km}$ from the capture site, but the female remained in close proximity to the park. While we did not locate the specific roosts, another tagged female traveled more than $2.7 \mathrm{~km}$ between roosting and foraging areas. For both tracked bats, distances between day roosts were under $0.1 \mathrm{~km}$ to 0.5 $\mathrm{km}$, which is consistent with studies in eastern North America, where mean travel distances between summer roosts are usually less than $0.8 \mathrm{~km}$, and generally within $0.7 \mathrm{~km}$ from the 
point of capture (Carter and Felhamer, 2005; Broders et al., 2006; Johnson et al., 2009; Silvis et al., 2016). In nearby Otoe County, Brack et al. (2019) documented distances of 3.4 and 2.1 $\mathrm{km}$ between capture sites and roosts of an adult non-reproductive female and an adult male, respectively, during summer, including traversing the Missouri River by the female. However, during autumn migration, a northern long-eared bat in nearby Sarpy County covered about $41 \mathrm{~km}$ in $2.8 \mathrm{~h}$ (White et al., 2017).

Northern long-eared bats often switch roosts, primarily using snags, crevices, cavities, and exfoliating bark of a variety of tree species (Cryan et al., 2001; Perry and Thill, 2007; Silvis et $a l ., 2012)$. We found 10 different roosts used within $0.1 \mathrm{~km}$ of Cub Creek on average, and only twice documented re-roosting on consecutive days by either bat. Like other studies (Patriquin et al., 2016; Rojas et al., 2017), we found roost use to be quite variable, including exfoliating bark on a burnt snag, a tree cavity, and multiple cavities of a shadow box fence. Stein and White (2016) found a maternity colony using cabins in southeastern Nebraska, perhaps driven by limited roost availability in a largely treeless landscape (Henderson and Broders, 2008), although the species readily uses bat boxes (Whitaker et al., 2006). Although our night tracking data was limited, individuals appeared to remain in close proximity to the riparian woodland corridor when foraging, a behavior documented in other agricultural studies (Henderson and Broders, 2008).

Our data shed light on the late-summer roosting habits and movements of this threatened species at the western edge of its range. The number of northern long-eared bats we caught over our sampling period is similar to that of the previous study in the Homestead National Monument (Robbins, 2005), and indicates successful reproduction, despite a landscape dominated by agriculture and the arrival of WNS to the area. Because northern long-eared bats used a variety of mature and young snags for daytime roosts, we recommend against removal of woody debris and other dead vegetation from forested areas. Before European settlement, trees were naturally restricted to riparian areas in Great Plains states, and as such, these natural woodland corridor habitats should be maintained to facilitate bat movement through the landscape (Geluso, 2006; Anderson et al., 2017). Anthropogenic structures also provide additional roosting opportunities for northern long-eared bats in Nebraska, and may prove vital for the persistence of forest-dependent bat species in landscapes with fewer tree roosts. Additional research is needed to understand the use of summer roosts and habitat by this declining species, at the edge of its range, on a landscape dominated by agriculture, to conserve this species in the face of rapid global change.

Acknowledgments.-This study was funded by the Homestead National Monument of America and is based upon work supported by the National Science Foundation under Grant No. DGE-1735362. Opinions, findings, conclusions, or recommendations are those of the author(s) and do not necessarily reflect views of the National Science Foundation. We obtained study approval from the University of Nebraska-Lincoln IACUC (project 1667), National Park Service scientific research and collecting permit HOME-2018-SCI-0002, and Nebraska Game and Parks scientific and education permit 1183-1. We thank park staff, especially M. Engler, J. Bolli, and J. Korgie for support, and the Nebraska Cooperative Fish and Wildlife Research Unit. We are grateful to B. Hale, A. Oetting, and Environmental Solutions \& Innovations, Inc. for assistance in conducting surveys. We thank Associate Editor Dr. K. Powers, Dr. A. Silvis, Dr. V. Brack, and anonymous reviewers for comments that improved the manuscript.

\section{Literature Cited}

AldRidge, H. AND R. M. BRIGHAM. 1988. Load carrying and maneuverability in an insectivorous bat: a test of the 5\% "rule." J. Mammal., 69:379-382. 
Anderson, B., K. Geluso, H. Otto, and L. Bishop-Boros. 2017. Westward expansion of the evening bat (Nycticeius humeralis) in the United States, with notes on the first record from New Mexico. West. N. Am. Nat., 77:223-229.

Anthony, E. L. P. 1988. Age determination in bats, p. 47-58. In T. H. Kunz (Ed.), Ecological and behavioral methods for the study of bats. Smithsonian Institution Press, Washington, D.C.

Blehert, D. S., A. C. Hicks, M. Behr, C. U. Meteyer, B. M. Berlowski-Zier, E. L. Buckles, J. T. H. Coleman, S. R. Darling, A. Gargas, R. Niver, J. C. Okoniewski, R. J. Rudd, and W. B. Stone. 2009. Bat Whitenose Syndrome: an emerging fungal pathogen? J. Sci., 323:227.

Brack, V. JR., D. W. Sparks and D. C. Brack. 2019. Bats of the Loess Hills ecoregion of southeast Nebraska. Prairie Nat., 51:47-57.

Broders, H. G. ANd G. J. Forbes. 2004. Interspecific and intersexual variation in roost-site selection of northern long-eared and little brown bats in the Greater Fundy National Park ecosystem. J. Wildl. Manage., 68:602-610.

Broders, H. G., G. J. Forbes, S. Woodley, And I. D. Thompson. 2006. Range extent and stand selection for roosting and foraging in forest-dwelling northern long-eared bats and little brown bats in the greater Fundy ecosystem, New Brunswick. J. Wildl. Manage., 70:1174-1184.

Caceres, M. C. and R. M. R. Barclay. 2000. Myotis septentrionalis. Mammalian Species, 634:1-4.

Carter, T. C. and G. A. Feldhamer. 2005. Roost tree use by maternity colonies of Indiana bats and northern long-eared bats in southern Illinois. Forest Ecol. and Manag., 219: 259-268.

Cryan, P. M., M. A. Bogdan, and G. M. Yanega. 2001. Roosting habits of four bat species in the Black Hills of South Dakota. Acta Chiropt., 3:43-52.

CZaplewski, N. J., J. P. Farney, J. K. Jones JR., and J. D. Druecker. 1979. Synopsis of bats of Nebraska. Occas. Pap. Mus., Texas Tech University, 61:1-24.

Foster, R. W. AND A. Kurta. 1999. Roosting ecology of the northern bat (Myotis septentrionalis) and comparisons with the endangered Indiana bat (Myotis sodalis). J. Mammal., 80:659-672.

Francl, K. E., W. M. Ford, D. W. Sparks, and V. Brack Jr. 2012. Capture and reproductive trends in summer bat communities in West Virginia: assessing the impact of White-nose Syndrome. J. Fish Wildl. Manag., 3:33-42.

Frick, W. F., S. J. Puechmaille, J. R. Hoyt, B. A. Nickel, K. E. Langwig, J. T. Foster, K. E. Barlow, T. Bartonička, D. Feller, Haarsma, A. J., C. Herzog, I. Horáček, J. van der Kooij, B. Mulkens, B. Petrov, R. Reynolds, L. Rodrigues, C. W. Stihler, G. G. Turner, and A. M. Kilpatrick. 2015. Disease alters macroecological patterns of North American bats. Glob. Ecol. Biogeogr., 24:741749 .

GeLuso, K. 2006. Bats in a human-made forest in central Nebraska. Prairie Nat., 38:13-23.

HaARsma, A. J. 2008. Manual for assessment of reproductive status, age, and health in European vespertilionid bats. Available online at https://www.researchgate.net/publication/228874636. Accessed 23 October 2020.

Henderson, L. E. ANd H. G. Broders. 2008. Movements and resource selection of the northern long-eared myotis (Myotis septentrionalis) in a forest-agriculture landscape. J. Mammal., 89:952-963.

Johnson, J. B., J. W. Edwards, W. M. Ford, and J. E. Gates. 2009. Roost tree selection by northern myotis (Myotis septentrionalis) maternity colonies following prescribed fire in a central Appalachian Mountains hardwood forest. For. Ecol. Manag., 258:233-242.

Lemen, C., P. Freeman, And J. White. 2016. Acoustic evidence of bats using rock crevices in winter: a call for more research on winter roosts in North America. TNAS, 36:9-13.

Patriquin, K. J. AND R. M. R. Barclay. 2003. Foraging by bats in cleared, thinned and unharvested boreal forest. J. Appl. Ecol., 40:646-657.

Patriquin, K. J., M. L. Leonard, H. G. Broders, W. M. Ford, E. R. Britzke and A. Silvis. 2016. Weather as a proximate explanation for fission-fusion dynamics in female northern long-eared bats. Anim. Behav., 122:47-57.

Perry, R. W. AND R. E. Thill. 2007. Roost selection by male and female northern long-eared bats in a pine-dominated landscape. For. Ecol. Manag., 247:220-226.

Prescott, G. W., D. P. Edwards, And W. A. Foster. 2015. Retaining biodiversity in intensive farmland: epiphyte removal in oil palm plantations does not affect yield. Ecol. Evol., 5:1944-1954. 
Ratcliffe, J. M. and J. W. Dawson. 2003. Behavioural flexibility: The little brown bat, Myotis lucifugus, and the northern long-eared bat, M. septentrionalis, both glean and hawk prey. Anim. Behav., 66:847856.

Reichard, J. D. and T. H. Kunz. 2009. White-nose Syndrome inflicts lasting injuries to the wings of little brown myotis (Myotis lucifugus). Acta Chiropt., 11:457-464.

Reinolds, R., K. Powers, W. Orndorff, M. W. Ford, and C. Hobson. 2016. Changes in rates of capture and demographics of Myotis septentrionalis (northern long-eared bat) in western Virginia before and after onset of White-nose Syndrome. Northeast Nat., 23:195-204.

RoBbins, L. 2005. Inventory of distribution, composition, and relative abundance of mammals, including bats at Homestead National Monument of America: Heartland Network, National Park Service.

Rojas, V., J. M. O'KeEFE, ANd S. C. Loeb. 2017. Baseline capture rates and roosting habits of Myotis septentrionalis (northern long-eared bat) prior to White-nose Syndrome detection in the southern Appalachians. Southeast. Nat., 16:140-148.

Silvis, A., W. M. Ford, E. R. Britzke, N. R. BeAne, ANd J. B. Johnson. 2012. Forest succession and maternity day roost selection by Myotis septentrionalis in a mesophytic hardwood forest. Int. J. For. Res., Available online at http://dx.doi. org/10.1155/2012/148106. Accessed 2 November 2020.

Silvis, A., R. W. Perry and W. M. Ford. 2016. Relationships of three species of bats impacted by Whitenose Syndrome to forest condition and management. General Technical Report SRS-214. US Forest Service, Southern Research Station, Asheville, NC. 57 pp.

Stein, R. And J. White. 2016. Maternity colony of northern long-eared myotis (Myotis septentrionalis) in a human-made structure in Nebraska. TNAS, 36:1-5.

Tilman, D., J. Fargione, B. Wolff, C. D’Antonio, A. Dobson, R. Howarth, D. Schindler, W. H. Schlesinger, D. SimberlofF, AND D. SWACKHAMER. 2001. Forecasting agriculturally driven global environmental change. J. Sci., 292:281-285.

US Fish and Wildlife Service. 2015. Endangered and Threatened Wildlife and Plants; Threatened Species Status for the Northern Long-Eared Bat With 4(d) Rule. Federal Register 80:17974-18033.

Whitaker, J. O. Jr., D. W. Sparks and V. Brack Jr. 2006. Use of artificial roost structures by bats at the Indianapolis International Airport. Environ. Manage., 38:28-36.

White, J., P. Freeman, H. Otto, B. Anderson and J. Hootman. 2017. Autumn migration of Myotis septentrionalis in Nebraska: documentation of fall activity migratory timing, and distance using radio-telemetry. TNAS, 37:40-46.

White, J., P. Freeman, H. Otto and C. Lemen. 2020. Winter use of a rock crevice by northern long-eared myotis (Myotis septentrionalis) in Nebraska. West. N. Am. Nat., 80:114-119.

White, J., C. Lemen and P. Freeman. 2016. Acoustic detection reveals fine-scale distributions of Myotis lucifugus, Myotis septentrionalis, and Perimyotis subflavus in eastern Nebraska. West. N. Am. Nat., 76:27-35.

White-Nosesyndrome.org. 2020. Accessed December 2020: https://www.whitenosesyndrome.org/ resources/map 